\title{
Effect of Dietary Yeast (Saccharomyces cerevisiae) Supplementation on Performance, Carcass Characteristics and Some Metabolic Responses of Broilers
}

\author{
Mohamed E. Ahmed ${ }^{*}$, Talha E. Abbas, Mojahid A. Abdlhag, Dafaalla E. Mukhtar \\ Department of Animal Production, Faculty of Agricultural Technology and Fish Science, University of ALneelain, Khartoum, Sudan
}

Email address:

moha_555@hotmail.com (M. E. Ahmed)

To cite this article:

Mohamed E. Ahmed, Talha E. Abbas, Mojahid A. Abdlhag, Dafaalla E. Mukhtar. Effect of Dietary Yeast (Saccharomyces cerevisiae) Supplementation on Performance, Carcass Characteristics and Some Metabolic Responses of Broilers. Animal and Veterinary Sciences. Special Issue: Poultry Welfare: Housing Systems and Feeding. Vol. 3, No. 5-1, 2015, pp. 5-10. doi: 10.11648/j.avs.s.2015030501.12

\begin{abstract}
This study was conducted to evaluate the effect of feeding graded levels of yeast on broiler performance, carcass characteristics and some hematological indices. One day old Hubbard broiler chicks $(\mathrm{n}=160)$ were randomly allocated to five dietary treatments. Each treatment consisted of 4 replicates of 8 broilers each. The dietary treatments contained $0 \%$ yeast (Saccharomyces cerevisiae) as a negative control diet, $0 \%$ yeast $+30 \mathrm{ppm}$ Oxytetracyline as a positive control, 1\%, 2\% and 3\% yeast in the starter and finisher diets. During the experimental periods of 6 weeks, feed intake, body weight gain and feed conversion ratio values were calculated. At the end of the experimental period (6 weeks of age), some biochemical and hematological indices, carcass characteristics traits and internal organs weights were recorded. Growth performance parameters were significantly $(\mathrm{P} \leq 0.05)$ affected by experimental diets. Chicks fed either 0 or $3 \%$ yeast recorded the highest $(\mathrm{P} \leq 0.05)$ feed intake, however, the best $(\mathrm{P} \leq 0.05)$ body weight gain was obtained by birds fed 0 or $1 \%$ dietary yeast compared to the positive control diet. The highest $(\mathrm{P} \leq 0.05)$ feed conversion ratio was reported for birds fed the positive control diet and $3 \%$ dietary yeast compared to the negative control diet. The inclusion of different dietary treatments had no significant ( $\mathrm{P} \geq 0.05)$ effects on dressing percentage, hot base and relative weights of heart, gizzard and abdominal fat. Nevertheless, birds fed $3 \%$ dietary yeast showed significant $(\mathrm{P} \leq 0.05)$ decrease in the relative weight of the liver compared to the negative control diet. Relative weights of breast and thigh were significantly $(\mathrm{P} \leq 0.05)$ higher in birds fed $1 \%$ yeast than those fed $3 \%$ yeast. There were linear decreases in serum cholesterol and albumin of broilers fed graded levels of dietary yeast. It is concluded that yeast can be included in broiler diet at $1 \%$ without detrimental effects on performance, and could therefore serve as a natural substitute for antibiotics.
\end{abstract}

Keywords: Saccharomyces cerevisiae, Broilers, Performance, Carcass, Hematology

\section{Introduction}

It is well documented that antibiotics benefit animal performance and health. They have long been included as a feed additive to increase broiler's growth performance and control of disease [1]. However, increasing concerns regarding overuse of antibiotics and bacterial resistance has encouraged extensive investigation into alternatives for sub-therapeutic antibiotics in feeds. Furthermore, use of probiotics, prebiotics and organic acids instead of antibiotics has increased in recent times. Probiotics act by competitive exclusion, lower gut $\mathrm{pH}$, produce bacteriocins, lysozyme and peroxides, and stimulate the immune system [2]. Some of the probiotic products contain Sacharomcyces spp varieties. Saccharomyces cerevisiae, from malted grains fermentation also known as "baker's yeast" is one of the most widely commercialized types of yeast, has long been fed to animals [3]. Moreover, yeast products are important natural growth promoters [4]. Yeast Saccharomyces cerevisiae is rich source of protein, vitamin B complex, trace minerals and many other beneficial factors [5].

The mode of action of Saccharomyces cerevisiae in enhancing animal performance is not fully understood. Yeasts may beneficially alter the inherent gut microbiota, possibly through controlling $\mathrm{pH}$. The presence of living yeast cells may also act as a reservoir for free oxygen, which could enhance growth of other anaerobes [6]. Effects of yeast products on production and their mode of action in poultry have been reported by $[7,8]$. Some studies have confirmed the effects of yeast culture in increasing concentrations of commensal 
microbes or suppressing pathogenic bacteria [7]. Reference [4] assumed that there may be other mechanisms responsible for effects of yeast culture in monogastrics other than modulation of microbial ecology. Mannan-oligosaccharide and 1,3/1,6 $\beta$-glucan are components of the yeast cell wall that have been reported to modulate immunity [9], promote growth of intestinal microflora [10], and increase growth [11]. Yeast culture contains viable cells, cell wall components, metabolites, and the media on which the yeast cells were grown [12]. In in vitro study, [13], postulated that the addition of a soluble fraction of yeast culture showed an anti-inflammatory effect in conjunction with activation of natural killer cells and B lymphocytes. In addition, others have reported that yeast products affect nutrient digestibility [14] and intestinal mucosal development $[15,8]$.

Reference [16] reported that active dry yeast effectively increases body weight gains without affecting feed/gain ratio in broiler chicks. On the other hand, supplementation of yeast to broiler diets improves feed/gain ratio but not growth rates [17]. In contrast, it has been reported that feeding yeast to chicks improves body weight gain and feed/gain ratio [18]. Recently, [3] indicated that SC supplementation did not affect broiler performance parameters and carcass characteristics. In addition, it has been reported that yeast could be used as an alternative for antibiotic-based drugs in feed in broiler chicks $[19,7]$.

The present study was therefore conducted to evaluate the effects of feeding graded levels of yeast (Saccharomyces cerevisiae) on broiler chicks performance, carcass characteristics and some blood parameters.

\section{Materials and Methods}

\subsection{Chickens and Treatments}

The current experiment was conducted in an open-sided poultry house at the premises of Faculty of Agricultural Technology and Fish Sciences, University of ALneelain. The ambient temperature during the experimental period in this location was $23-39{ }^{\circ} \mathrm{C}$. One day old Hubbard broiler chicks $(n=160)$ were randomly assigned to five dietary treatments, containing $0 \%$ yeast (Saccharomyces cerevisiae) as a negative control diet, $0 \%$ yeast $+30 \mathrm{ppm}$ Oxytetracyline as a positive control, and 3 graded levels of yeast Saccharomyces cerevisiae $(1 \%, 2 \%$ and $3 \%)$. Each treatment was replicated 4 times with 8 birds per replicate. Experimental diets were formulated according to [20], to be fed during starter period (0-3 weeks) (Table 1) and finisher period (4-6 weeks) (Table 2 ). Each pen was provided with feeder and drinker. Feed and water were offered ad libitum.

Table 1. Composition of experimental broiler starter (1-3 weeks) diets containing graded levels of dietary yeast (Saccharomyces cerevisiae).

\begin{tabular}{lllll}
\hline \multirow{2}{*}{ Ingredients\% } & \multicolumn{4}{l}{ Dietary Treatments } \\
\cline { 2 - 5 } & $\mathbf{0 \%}$ yeast & $\mathbf{1 \%}$ yeast & $\mathbf{2 \%}$ yeast & 3\% yeast \\
\hline Sorghum & 64.00 & 64.00 & 64.05 & 64.83 \\
Ground nut cakes & 24.67 & 23.75 & 22.79 & 21.02 \\
Wheat bran & 1.00 & 1.00 & 1.00 & 1.00 \\
\hline
\end{tabular}

\begin{tabular}{|c|c|c|c|c|}
\hline \multirow{2}{*}{ Ingredients\% } & \multicolumn{4}{|c|}{ Dietary Treatments } \\
\hline & 0\% yeast & $1 \%$ yeast & $2 \%$ yeast & $3 \%$ yeast \\
\hline $\begin{array}{l}\text { Super } \\
\text { concentrates }\end{array}$ & 5.00 & 5.00 & 5.00 & 5.00 \\
\hline L-Lysine & 0.20 & 0.10 & 0.10 & 0.10 \\
\hline DL-Methionine & 0.13 & 0.12 & 0.11 & 0.11 \\
\hline Lime stone & 1.00 & 1.10 & 1.10 & 1.18 \\
\hline $\begin{array}{l}\text { Dicalcium } \\
\text { phosphate }\end{array}$ & 0.60 & 0.53 & 0.45 & 0.36 \\
\hline Vegetable oil & 3.00 & 3.00 & 3.00 & 3.00 \\
\hline Choline & 0.10 & 0.10 & 0.10 & 0.10 \\
\hline Enzymes & 0.10 & 0.10 & 0.10 & 0.10 \\
\hline Mycotoxin binder & 0.2 & 0.2 & 0.2 & 0.2 \\
\hline Yeast & 0.00 & 1.00 & 2.00 & 3.00 \\
\hline \multicolumn{5}{|l|}{$\begin{array}{l}\text { Calculated } \\
\text { analysis }\end{array}$} \\
\hline ME (kcal/kg) & 3171.72 & 3162.61 & 3157.81 & 3155.66 \\
\hline $\mathrm{CP} \%$ & 23.41 & 23.28 & 23.23 & 22.88 \\
\hline $\mathrm{Ca} \%$ & 1.01 & 1.03 & 1.01 & 1.01 \\
\hline Available P\% & 0.46 & 0.45 & 0.45 & 0.45 \\
\hline Lysine $\%$ & 1.11 & 1.06 & 1.08 & 1.09 \\
\hline Methionine\% & 0.52 & 0.52 & 0.51 & 0.51 \\
\hline $\begin{array}{l}\text { Methionine+Cyst } \\
\text { ine } \%\end{array}$ & 0.74 & 0.74 & 0.73 & 0.73 \\
\hline
\end{tabular}

Table 2. Composition of experimental broiler finisher (3-6 weeks) diets containing graded levels of dietary yeast (Saccharomyces cerevisiae).

\begin{tabular}{|c|c|c|c|c|}
\hline \multirow{2}{*}{ Ingredients \% } & \multicolumn{4}{|c|}{ Dietary Treatments } \\
\hline & $0 \%$ yeast & $1 \%$ yeast & $2 \%$ yeast & $3 \%$ yeast \\
\hline Sorghum & 64.00 & 64.00 & 64.05 & 64.83 \\
\hline Ground nut cakes & 24.67 & 23.75 & 22.79 & 21.02 \\
\hline Wheat bran & 1.00 & 1.00 & 1.00 & 1.00 \\
\hline $\begin{array}{l}\text { Super } \\
\text { concentrates }\end{array}$ & 5.00 & 5.00 & 5.00 & 5.00 \\
\hline L-Lysine & 0.20 & 0.10 & 0.10 & 0.10 \\
\hline DL-Methionine & 0.13 & 0.12 & 0.11 & 0.11 \\
\hline Lime stone & 1.00 & 1.10 & 1.10 & 1.18 \\
\hline $\begin{array}{l}\text { Dicalcium } \\
\text { phosphate }\end{array}$ & 0.60 & 0.53 & 0.45 & 0.36 \\
\hline Vegetable oil & 3.00 & 3.00 & 3.00 & 3.00 \\
\hline Choline & 0.10 & 0.10 & 0.10 & 0.10 \\
\hline Enzymes & 0.10 & 0.10 & 0.10 & 0.10 \\
\hline Mycotoxin binder & 0.2 & 0.2 & 0.2 & 0.2 \\
\hline Yeast & 0.00 & 1.00 & 2.00 & 3.00 \\
\hline \multicolumn{5}{|l|}{$\begin{array}{l}\text { Calculated } \\
\text { analysis }\end{array}$} \\
\hline $\mathrm{ME}(\mathrm{kcal} / \mathrm{kg})$ & 3152.28 & 3157.38 & 3150.28 & 3154.68 \\
\hline $\mathrm{CP} \%$ & 19.15 & 18.98 & 18.91 & 18.46 \\
\hline $\mathrm{Ca} \%$ & 0.82 & 0.82 & 0.81 & 0.80 \\
\hline Available P\% & 0.34 & 0.35 & 0.36 & 0.38 \\
\hline Lysine $\%$ & 0.85 & 0.87 & 0.89 & 0.90 \\
\hline Methionine\% & 0.37 & 0.37 & 0.37 & 0.37 \\
\hline $\begin{array}{l}\text { Methionine }+ \text { Cyst } \\
\text { ine } \%\end{array}$ & 0.55 & 0.55 & 0.55 & 0.54 \\
\hline
\end{tabular}

\subsection{Management}

Continuous lighting was provided throughout the experimental period extended from 13/3/2012 to 24/4/2012. Broilers were vaccinated with mix (IB Ma5 + Newcastle clone 30 ) on day 7 , and Gumboro D78 vaccine at 14 days of age, and replicated at 21 days of age. Finally, the birds were vaccinated against Newcastle (live clone 30) at 28 days of age. Feed 
intake and body weight were measured weekly for starter, finisher and the whole period. Mortality was recorded during the experiment as it occurred. Average feed intake, body weight gain and feed conversion ratio (feed/gain) were calculated for starter, finisher, and overall periods.

\subsection{Samples Collection and Analysis}

At the end of the feeding trial (6 weeks of age), the birds were fasted overnight and weighed. Two birds from each pen were selected at random and slaughtered following Halal method. This method is in accordance with Islamic rites, which considered as the least painful one. Blood samples were collected from jugular vein during slaughtering process. Hematological indices examined include packed cell volume (PCV), cholesterol, triglycerides, total protein, albumin and globulin. The same samples of birds were used for carcass characteristics analysis. These birds were de-feathered completely using warm water, decapitated, eviscerated and weighed again to obtain the dressed weights. Dressing out percentage was calculated as a percentage of live weight. The weights of liver, heart, gizzard, abdominal fat, breast, thigh and drumstick were expressed as percentage proportion of dressed weights.

\subsection{Statistical Analysis}

The experiment was arranged in a completely randomized design. Statistical analysis of the data was carried out using the General Linear Models procedure of SAS version 9.0 for Windows [21, 22]. Duncan's Multiple Range Test was used to detect significant differences between treatment means.

\section{Results and Discussion}

The effects of feeding graded levels of yeast Saccharomyces cerevisiae on the growth performance of broiler chicks are shown in Table 3. During the starter period (0-3 wk), dietary treatments did not affect $(\mathrm{P} \geq 0.05)$ broiler performance parameters. However, during the finisher (4-6 wk) and overall (4-6 wk) periods, supplemental yeast, significantly $(\mathrm{P} \leq 0.05)$ affected growth performance. During these periods, $3 \%$ dietary yeast significantly $(\mathrm{P} \leq 0.05)$ increased feed intake when compared to the positive control. Similar results were reported by [4]. Moreover, body weight gain at different levels of yeast was not different $(\mathrm{P} \geq 0.05)$ from either negative or positive controls. Nevertheless, overall body weight gain increased $(\mathrm{P} \leq 0.05)$ in birds fed on $1 \%$ dietary yeast compared with the positive control during the entire period ( 0 to 6 weeks of age). These findings are in line with the results obtained by [3], who claimed no negative effect of yeast on the growth performance of broiler chickens. The improved body weight gain with yeast supplementation was not due to increased feed intake, and similar results were reported by [4]. On the other hand, a poorer feed conversion ratio was observed in birds fed 3\% yeast and positive control compared with negative control. Likewise, [16] demonstrated that active dry yeast increased weight gain without affecting feed conversion ratio in broiler chicks. In contrast with our study, some authors found that the use of yeast cell in broiler diets improved feed conversion ratio [17]. This may be because that in the previous study high-fiber $(5.02 \%)$ and low-protein (18\%) diets were used, and it has been reported that high-fiber diet [23] and low-protein diet [24] reduce feed efficiency.

Table 3. Effects of graded levels of dietary yeast (Saccharomyces cerevisiae) on broiler performance.

\begin{tabular}{|c|c|c|c|c|c|c|}
\hline \multirow{2}{*}{ Parameters } & \multicolumn{6}{|c|}{ Dietary Treatments } \\
\hline & $0 \%$ yeast & 0\%yeast + Oxytetracyclin & $1 \%$ yeast & $2 \%$ yeast & $3 \%$ yeast & \pm SEM \\
\hline \multicolumn{7}{|l|}{$0-3 \mathrm{wk}$} \\
\hline Feed Intake & $1379.7 \pm 91.06$ & $1317.5 \pm 4.86$ & $1332.9 \pm 30.93$ & $1357.3 \pm 14.28$ & $1339.7 \pm 20.01$ & 22.22 \\
\hline Body W. Gain & $729.8 \pm 40.80$ & $695.7 \pm 50.44$ & $733.6 \pm 10.25$ & $690.9 \pm 44.31$ & $712.6 \pm 24.26$ & 18.53 \\
\hline FCR & $1.90 \pm 0.20$ & $1.90 \pm 0.13$ & $1.82 \pm 0.06$ & $1.97 \pm 0.12$ & $1.88 \pm 0.06$ & 0.06 \\
\hline \multicolumn{7}{|l|}{$4-6 \mathrm{wk}$} \\
\hline Feed Intake & $1951.85^{\mathrm{au}} \pm 94.63$ & $1850.21^{\mathrm{v}} \pm 88.34$ & $1961.94^{\mathrm{au}} \pm 37.72$ & $1926.99^{\mathrm{a} u} \pm 46.33$ & $2016.09^{\mathrm{a}} \pm 51.32$ & 33.88 \\
\hline Body W. Gain & $1132.59^{\mathrm{a}} \pm 106.17$ & $931.25^{\mathrm{D}} \pm 70.71$ & $1072.32^{\mathrm{ad}} \pm 42.07$ & $1068.75^{\mathrm{ad}} \pm 90.28$ & $1015.40^{\mathrm{ac}} \pm 43.60$ & 37.48 \\
\hline FCR & $1.73^{\mathrm{D}} \pm 0.08$ & $1.99^{\mathrm{a}} \pm 0.16$ & $1.83^{\mathrm{av}} \pm 0.06$ & $1.81^{\mathrm{av}} \pm 0.12$ & $1.99^{\mathrm{a}} \pm 0.11$ & 0.06 \\
\hline \multicolumn{7}{|l|}{$0-6 \mathrm{wk}$} \\
\hline Feed Intake & $3331.5^{\mathrm{a}} \pm 172.4$ & $3167.7^{\cup} \pm 91.7$ & $3294.8^{\mathrm{a} u}{ }_{ \pm 52.5}$ & $3284.3^{\mathrm{au}} \pm 57.1$ & $3355.8^{\mathrm{a}} \pm 31.7$ & 47.51 \\
\hline Body W. Gain & $1862.4^{\mathrm{a}} \pm 124.9$ & $1626.9^{\mathrm{D}} \pm 91.2$ & $1805.9^{\mathrm{a}} \pm 50.0$ & $1759.6^{\mathrm{ad}} \pm 79.3$ & $1728.0^{\mathrm{ad}} \pm 67.0$ & 43.11 \\
\hline FCR & $1.79^{\mathrm{U}} \pm 0.09$ & $1.95^{\mathfrak{a}} \pm 0.1$ & $1.83^{\mathrm{au}} \pm 0.05$ & $1.87^{\mathrm{au}} \pm 0.06$ & $1.94^{\mathrm{a}} \pm 0.08$ & 0.04 \\
\hline
\end{tabular}

Values are means of 4 replicates per treatment ( 8 birds/ replicate).

${ }^{\mathrm{a}}$ Means with different superscripts in the same row were significantly different $(\mathrm{P} \leq 0.05)$.

SEM: Standard error of the means from ANOVA d.f 15.

The results of the effects of dietary yeast supplementation on carcass weight and relative organs weight are presented in Table 4. Except for dressing \% and relative weight of heart, gizzard and abdominal fat, all carcass parameters and internal organs weights were significantly $(\mathrm{P} \leq 0.05)$ affected by dietary treatments. However, $[3,25]$ revealed that dietary yeast had no effect on carcass characteristics. On the other hand, [26] stated that addition of dietary yeast at all levels improve carcass characteristics of broilers. These different results may be due to dose or kind of yeast used, strain of broilers, basal diet or 
environmental conditions

Table 4. Effects of graded levels of dietary yeast (Saccharomyces cerevisiae) on some carcass characteristics and internal organs of broilers.

\begin{tabular}{|c|c|c|c|c|c|c|}
\hline \multirow{2}{*}{ Parameters } & \multicolumn{6}{|c|}{ Dietary Treatments } \\
\hline & $0 \%$ yeast & 0\%yeast + Oxytetracyclin & $1 \%$ yeast & $2 \%$ yeast & $3 \%$ yeast & \pm SEM \\
\hline Dressing\% & $72.23 \pm 5.2$ & $70.10 \pm 4.1$ & $69.93 \pm 2.5$ & $72.23 \pm 1.8$ & $73.08 \pm 0.76$ & 1.64 \\
\hline R. W. of heart & $0.64 \pm 0.06$ & $0.68 \pm 0.15$ & $0.65 \pm 0.07$ & $0.59 \pm 0.03$ & $0.62 \pm 0.11$ & 0.05 \\
\hline R. W. of gizzard & $2.77 \pm 1.54$ & $2.23 \pm 0.41$ & $2.18 \pm 0.09$ & $2.24 \pm 0.17$ & $1.99 \pm 0.27$ & 0.36 \\
\hline R. W. of A. Fat & $2.58 \pm 0.53$ & $2.60 \pm 0.24$ & $3.49 \pm 0.71$ & $2.61 \pm 0.52$ & $3.16 \pm 0.80$ & 0.30 \\
\hline R. W. of liver & $3.53^{a} \pm 0.51$ & $3.09^{\mathrm{av}} \pm 0.99$ & $2.88^{a v} \pm 0.43$ & $2.63^{a v} \pm 0.56$ & $2.2^{\mathrm{v}} \pm 0.15$ & 0.30 \\
\hline $\mathrm{R}$. weight of $\mathrm{Br}$ & $14.44^{a v} \pm 3.04$ & $16.98^{a v} \pm 2.35$ & $19.05^{a} \pm 2.14$ & $17.16^{a v} \pm 3.85$ & $14.00^{\circ} \pm 2.57$ & 1.43 \\
\hline $\mathrm{M} / \mathrm{B} \mathrm{Br}$ & $5.01^{a} \pm 0.01$ & $3.98^{a} \pm 2.03$ & $4.98^{a} \pm 0.06$ & $2.50^{\circ} \pm 0.00$ & $4.77^{a} \pm 0.47$ & 0.47 \\
\hline Thig rel & $7.54^{a v} \pm 1.13$ & $6.83^{a \mathrm{u}} \pm 0.95$ & $8.31^{a} \pm 1.27$ & $7.66^{a v} \pm 1.26$ & $6.07^{\mathrm{v}} \pm 0.67$ & 0.54 \\
\hline $\mathrm{m} / \mathrm{b}$ thigh & $5.58^{a v} \pm 0.07$ & $5.87^{a} \pm 0.32$ & $4.74^{u \sim} \pm 1.24$ & $4.92^{u} \pm 0.18$ & $4.07^{2} \pm 0.30$ & 0.30 \\
\hline Drum rela & $7.27^{\circ} \pm 0.80$ & $9.21^{a} \pm 2.06$ & $7.93^{a v} \pm 0.49$ & $8.25^{\mathrm{av}} \pm 1.11$ & $9.22^{\mathrm{a}} \pm 0.38$ & 0.57 \\
\hline Drum m/b & $3.97^{a} \pm 0.06$ & $3.62^{v} \pm 0.11$ & $3.61^{\mathrm{v}} \pm 0.00$ & $2.93^{\iota} \pm 0.16$ & $3.87^{a} \pm 0.26$ & 0.07 \\
\hline
\end{tabular}

Values are means of 4 replicates per treatment.

abc Means with different superscripts in the same row were significantly different $(\mathrm{P} \leq 0.05)$.

SEM: Standard error of the means from ANOVA d.f 15.

Table 5. Effects of graded levels of dietary yeast (Saccharomyces cerevisiae) on some serum metabolites and haematology of broilers

\begin{tabular}{|c|c|c|c|c|c|c|}
\hline \multirow{2}{*}{ Parameters } & \multicolumn{6}{|c|}{ Dietary Treatments } \\
\hline & $0 \%$ yeast & $0 \%$ yeast + Oxytetracyclin & $1 \%$ yeast & $2 \%$ yeast & $3 \%$ yeast & \pm SEM \\
\hline Cholesterol mg/dL & $176.00^{a} \pm 7.00$ & $172.33^{a} \pm 3.51$ & $150.00^{\mathrm{au}} \pm 11.00$ & $148.00^{a v} \pm 14.00$ & $141.67^{\mathrm{U}} \pm 25.41$ & 8.40 \\
\hline Triglycerides & $45.00 \pm 10.44$ & $45.00 \pm 9.64$ & $46.57 \pm 15.23$ & $40.57 \pm 14.56$ & $46.57 \pm 8.45$ & 5.10 \\
\hline Total Protein g/dL & $2.72 \pm 1.24$ & $2.81 \pm 0.60$ & $2.45 \pm 0.72$ & $2.05 \pm 0.35$ & $2.13 \pm 0.38$ & 0.42 \\
\hline Albumin g/dL & $1.50^{\mathrm{av}} \pm 0.51$ & $1.56^{a} \pm 0.22$ & $1.29^{\mathrm{au}} \pm 0.39$ & $0.85^{\mathrm{uL}} \pm 0.37$ & $0.79^{\iota} \pm 0.07$ & 0.19 \\
\hline Globulin $\mathrm{g} / \mathrm{dL}$ & $1.22 \pm 0.76$ & $1.25 \pm 0.39$ & $1.17 \pm 0.46$ & $1.20 \pm 0.20$ & $1.33 \pm 0.44$ & 0.27 \\
\hline PCV\% & $31.00^{\mathrm{a}} \pm 1.00$ & $29.67^{\mathrm{av}} \pm 5.80$ & $31.33^{a} \pm 0.46$ & $28.00^{\mathrm{au}} \pm 2.00$ & $24.67^{\mathrm{v}} \pm 1.15$ & 1.77 \\
\hline
\end{tabular}

Values are means of 3 replicates per treatment.

Means with different superscripts in the same row were significantly different $(\mathrm{P} \leq 0.05)$.

SEM: Standard error of the means from ANOVA d.f 10.

Table 5 shows the effects of graded levels of dietary yeast on biochemical and haematological indices of broilers. There were no significant $(\mathrm{P} \geq 0.05)$ differences across the different dietary treatments in serum levels of total protein, globulin and triglycerides. These results are in line with the results obtained by [27] who reported that inclusion of yeast into diets of turkey toms doesn't affect serum levels of total protein, globulin and triglycerides. Reference [28] also, found serum levels of protein and triglycerides were unaffected by dietary $S$ cerevisiae. In addition, reference [29] declared that there is no significant influence of dietary $S$ cerevisiae on serum triglycerides. In reverse to these findings, [26] noticed that dietary yeast decreases serum triglycerides and increases serum concentrations of protein and globulin. Cholesterol, albumin, and PCV were significantly $(\mathrm{P} \leq 0.05)$ affected by dietary treatments. There were linear decreases in serum cholesterol and albumin of broilers fed graded levels of dietary yeast compared to negative and positive control. References [30,31] assured that dietary yeast causes decrease in serum cholesterol when added to broilers diets. Reference [32] confirmed decrease in serum albumin when $2 \%$ of yeast culture was added to Japanese quails diets. Opposite to these results [26] mentioned increase in serum albumin as a result of supplementation of yeast to broilers diets. Different results also, obtained by [33] who found supplementation of yeast derived $\beta$-glucan has no effect on various concentrations of cholesterol fractions. On the other hand, broilers on $3 \%$ dietary yeast expressed significantly $(\mathrm{P} \leq 0.05)$ lowest $\mathrm{PCV}$ compared to negative and positive control. This might be due to higher level of yeast used in the experiment. Reference [34] mentioned that increased level of yeast supplementation resulted in increased bacterial load on the bird gut. In reverse to this result [31] reported that dietary yeast has no effects on PCV when introduced into broilers diet. Different results may be due to different dose or kind of yeast used, experimental conditions, basal diet or strain of broilers.

\section{Conclusion}

It was concluded that yeast can be included in broiler diets at $1 \%$ without detrimental effects on performance, and might therefore serve as a natural substitute for antibiotics. More research is however required in both experimental and productive conditions to confirm this conclusion.

\section{References}

[1] Chen KL, Kho WL, You SH, Yeh RH, Tang SW, Hsieh CW. Effects of Bacillus subtilis var. natto and Saccharomyces cerevisiae mixed fermented feed on the enhanced growth performance of broilers. Poult Sci. 2009; 88: 309-315. 
[2] Grashorn MA. Use of phytobiotics in broiler nutrition- an alternative to infeed antibiotics. J Anim Feed Sci. 2010; 19: 338-347.

[3] Rezaeipour V, Fononi H, Irani M. Effects of dietary L-threonine and Saccharomyces cerevisiae on performance, intestinal morphology and immune response of broiler chickens. SA J Anim Sci. 2012; 42: 266-273.

[4] Gao J, Zhang HJ, Yu SH, Wu SG, Yoon I, Quigley J, Gao YP, Qi GH. Effects of yeast culture in broiler diets on performance and immunomodulatory functions. Poult Sci. 2008; $87: 1377-1384$.

[5] Reed G, Nagodawithana TW. Yeast Technology. $2^{\text {nd }}$ edition New York: Van Nostrand Reinhold, USA. 1991.

[6] Leeson S, Summers JD. Commercial Poultry Nutrition. $3^{\text {rd }}$ Edition. Nottingham University Press, England. 2008.

[7] Stanley VG, Gray C, Daley M, Krueger WF, Sefton AE. An alternative to antibiotic-based drugs in feed for enhancing performance of broilers grown on Eimeria spp.-infected litter. Poult Sci. 2004; 83:39-44.

[8] Zhang AW, Lee BD, Lee SK, Lee KW, An GH, Song KB, Lee $\mathrm{CH}$. Effects of yeast (Saccharomyces cerevisiae) cell components on growth performance, meat quality, and ileal mucosa development of broiler chicks. Poult Sci. 2005; 84: $1015-1021$.

[9] Shashidhara RG, Devegowda G. Effect of dietary mannan oligosaccharide on broiler breeder production traits and immunity. Poult Sci. 2003; 82: 1319-1325.

[10] Spring P, Wenk C, Dawson KA, Newman KE. The effects of dietary mannanoligosaccharides on cecal parameters and the concentrations of enteric bacteria in the ceca of Salmonella-challenged broiler chicks. Poult Sci. 2000; 79: 205-211.

[11] Parks CW, Grimes JL, Ferket PR, Fairchild AS. The effect of mannanoligosaccharides, bambermycins, and virginiamycin on performance of large white male market turkeys. Poult Sci. 2001; 80: 718-723.

[12] Miles RD, Bootwalla SM. Direct-fed microbials in animal production 'avian'. In Direct-Fed Microbials in Animal Production-A Review of the literature. NFIA, West Des Moines, Iowa, US. 1991; 117-146

[13] Jensen GS, Patterson KM, Yoon I. Yeast culture has anti-inflammatory effects and specifically activates NK cells. Comp Immunol Microbiol Infect Dis. 2008; 31: 487-500.

[14] Bradley GL, Savage TF. The effect of autoclaving a yeast culture of Saccharomyces cerevisiae on turkey poult performance and the retention of gross energy, and selected minerals. Anim Feed Sci Technol. 1995; 55: 1-7.

[15] Santin E, Maiorka A, Macari M, Grecco M, Sanchez JC, Okada TM, Myasaka AM. Performance and intestinal mucosa development of broiler chickens fed diets containing Saccharomyces cerevisiae cell wall. J Appl Poult Res. 2001; 10: 236-244.

[16] Kanat R, Calialar S. A research on the comparison effect on broiler chickens performance of active dried yeast and inactivated and stabilized probiotic yeast supplemented to the rations in different levels. Poult. Sci. 1996; 75 (Suppl. 1):123 (Abstract).
[17] Onifade AA, Odunsi AA, Babatunde GM, Olorede BR, Muma E. Comparison of the supplemental effects of Saccharomyces cerevisiae and antibiotics in low-protein and high-fiber diets fed to broiler chicken. Arch Anim Nutr. 1999; 52: 29-39.

[18] Onifade AA, Babatunde GM, Afonja SA, Ademola SG, Adesina EA. The effect of a yeast culture addition to a low-protein diet on the performance and carcass characteristics of broiler chickens. Poult Sci. 1998; 77 (Suppl. 1): 44. (Abstract).

[19] Hooge DM, Sims MD, Sefton AE, Connolly A, Spring P. Effect of dietary mannan oligosaccharide, with or without bacitracin or virginiamycin, on live performance of broiler chickens at relatively high stocking density on new litter. J Appl Poult Res. 2003; 12: 461-467.

[20] National Research Council. Nutrient Requirement of Poultry. Ninth revised edition, National Academy Press, Washington DC. $1994 ; 19-26$

[21] SAS Institute, Inc. SAS/STAT(R) User's Guide, Version 9, Cary, NC: SAS Institute, Inc. 2003.

[22] Steel RGD, Torrie JH. Principles and Procedures of Statistics. A Biometrical Approach. 2nd ed. McGraw-Hill Book Co, Inc, New York, NY. 1980.

[23] Krás RV, Kessler AM, Ribeiro AML, Henn JDi, Santos 11 dos, Halfen DP, Bockor L. Effect of dietary fiber and genetic strain on the performance and energy balance of broiler chickens. Braz J Poult Sci. 2013; 15: 15-20.

[24] Bregendahl K, Sell JL, Zimmerman DR. Effect of low-protein diets on growth performance and body composition of broiler chicks. Poult Sci. 2002; 81: 1156-1167.

[25] Karaoglu M, Durdag H. The influence of dietary probiotic (Saccharomyces cerevisiae) supplementation and different slaughter age on the performance, slaughter and carcass properties of broilers. Int J Poult Sci. 2005; 4: 309-316.

[26] Paryad A, Mahmoudi M. Effect of different levels of supplemental yeast (Saccharomyces cerevisiae) on performance, blood constituents and carcass characteristics of broiler chicks. Afr J Agr Res. 2008; 12: 835-842.

[27] Konca Y, Kirkpinar F, Mert S, Kayhan B. Performance, intestinal microflora and blood constituents in finishing turkeys fed diets supplemented with dietary mannan oligosaccharide and live yeast. J Anim Feed Sci. 2009; 18: 508-517.

[28] Yalçın S, Eser H, Yalçın S, Cengiz S, Eltan Ö. Effects of dietary yeast autolysate (Saccharomyces cerevisiae) on performance, carcass and gut characteristics, blood profile, and antibody production to sheep red blood cells in broilers. J Appl Poult Res. 2013; 22: 55-61.

[29] Pouraziz S, Shahryar HA, Chekani-Azar S. Effects of dietary Saccharomyces cerevisiae and butyric acid glycerides on performance and serum lipid level of broiler chickens. Kafkas Univ Vet Fak Derg. 2013; 19: 903-907.

[30] Aluwong T, Raji MA, Hassan BF, Kawu MU, Kobo PI, Ayo JO. Effect of different levels of supplemental yeast on performance indices and serum biochemistry of broiler chickens. The Open Conf Proc J. 2012; 3(Suppl 1-M7): 41-45.

[31] Saied JM, Al-Jabary QH, Thalij KM. Effect of dietary supplement yeast culture on production performance and hematological parameters in broiler chicks. Int J Poult Sci. 2011; 10: 376-380. 
[32] Ghally KA, Abd El-Latif SA. Effect of dietary yeast on some productive and physiological aspects on growing Japanese quails. Afr Crop Sci Conf Proc. 2007; 8: 2147-2151.

[33] An BK, Cho BL, You SJ, Paik HD, Chang HI, Kim SW, Yun $\mathrm{CW}$, Kang CW. Growth performance and antibody response of broiler chicks fed yeast derived $\beta$-glucan and single-strain probiotics. Asian-Aust J Anim Sci. 2008; 21: 1027-1032.

[34] Onwurah FB, Okejim J, Amaefula KU. Effect of yeast as water additive in the management of litter in the production starter broiler. Asi J Natu Appl Sci. 2013; 2: 27-30. 